Маслей Віктор, ORCID iD 0000-0001-8512-4974, E-mail :vmasley101@gmail.com

\title{
ВИЗНАЧЕННЯ КРИТИЧНОГО ПРОТИРІЧЧЯ У ФУНКЦІОНУВАННІ СИСТЕМИ УПРАВЛІННЯ ПОПЕРЕДЖЕННЯМ ТА МІНІМІЗАЦІЕЮ НАСЛІДКІВ НАДЗВИЧАЙНИХ СИТУАЦІЙ
}

\section{https://doi.org/10.32689/2618-0065-2021-1(7)-180-194}

Анотація. Найактуальнішою проблемою в умовах сьогодення, яке сповнене значною кількістю надзвичайних ситуацій із значним обсягом їх наслідків, $\epsilon$ підвищення безпеки населення під час їх виникнення. Завдяки роботі органів виконавчої влади, місцевого самоврядування, Державної служби України 3 надзвичайних ситуацій, наукових установ напрацьовано та ухвалено низку законодавчих i нормативно-правових актів, що налагоджують управління запобіганням та ліквідацією наслідків надзвичайних ситуацій, нагромаджено вагомий досвід у здійсненні заходів щодо запобігання аваріям, катастрофам та стихійному лиху, а також усунення їх наслідків. В статті окреслено недоліки заходів реагування та мінімізації наслідків надзвичайних ситуацій, що полягають в наявності упущень в системі управління реагуванням на них, в ухваленні не популярних та не аргументованих рішень при здійсненні аварійно-рятувальних та інших невідкладних робіт, недостатній рівень кількісно-якісних показників спеціального математичного та програмного забезпечення моделювання вказаних заходів. Критичним протиріччям функціонування системи управління попередженням та мінімізацією наслідків надзвичайних ситуацій визначено протиріччя між необхідністю достатнього рівня матеріально-технічного та фінансового забезпечення системи управління попередженням та мінімізацією наслідків виникнення надзвичайних ситуацій та низьким рівнем наявного матеріального резерву, що повинен створюватися органами управління ЄДСЦЗ всіх рівнів. В статті проаналізовано нормативноправове забезпечення створення матеріальних резервів 3 метою визначення ступені відповідальності органів влади різного рівня щодо їх створення.

Надано пропозиції щодо подолання зазначеного критичного протиріччя, а саме визначення найоптимальнішого протоколу державного резервування для України; удосконалення системної нормативно-правової бази; напрацювання методів визначення номенклатури матеріальних цінностей; реконструкція підприємств, які належать до системи держрезерву. Також головним визначено створення системи логістики матеріальним резервом, дано авторське визначення цієї дефініції.

Ключові слова: надзвичайна ситуація, Державна служба України 3 надзвичайних ситуацій, матеріальний резерв, державний матеріальний резерв, система управління, матеріально-технічне забезпечення, попередження та мінімізація наслідків надзвичайних ситуацій. 
Постановка проблеми. На сьогодні забезпечення та підвищення безпеки мешканців під час надзвичайних ситуацій (далі - НС) стає однією 3 найбільш головних соціальнополітичних, економічних, соціально-демографічних та екологічних проблем. Загроза виникнення надзвичайних ситуацій в Україні є високою. Збільшується обсяг їх наслідків, що ставить завдання щодо їх мінімізації перед органами управління єдиної державної системи цивільного захисту України (далі - СДСЦЗ). В останні роки зусиллями робочих груп представників органів виконавчої влади та місцевого самоврядування, Державної служби України 3 надзвичайних ситуацій (далі - ДСНС), наукових та освітніх установ цивільного захисту напрацьовано та ухвалено низку законодавчих і нормативно-правових актів. Це дозволило створити законодавчу та нормативно-правову базу функціонування системи управління запобіганням та мінімізацією наслідків надзвичайних ситуацій. Оперативнорятувальними силами накопичено вагомий досвід у здійсненні заходів щодо запобігання аваріям, катастрофам та стихійному лиху, а також усунення їх наслідків.

Однак, існують протиріччя функціонування системи управління ЄДСЦЗ. Практика свідчить, що у більшому ступені зусилля спрямовані на реагування і ліквідацію наслідків НC, а проблема попередження та мінімізація наслідків їх виникнення стоїть в осторонь. Пошук протиріч, що пов'язані із функціонуванням системи управління попередженням та мінімізацією наслідків НC та обгрунтування шляхів їх розв'язання $\epsilon$ сучасною науковою проблематикою науки публічного управління та адміністрування.

Мета статті. На основі аналізу публікацій 3 проблем системи управління СДСЦЗ в цілому та ії складової - системи управління попередженням та мінімізацією наслідків надзвичайних ситуацій визначити критичне протиріччя функціонування останньої, що вимагає негайного розв'язання й запропонувати кроки щодо його подолання.

Аналіз попередніх досліджень та публікацій. Головні завдання вивчення процесу утворення ідентифікованих джерел 
небезпеки, що за деяких обставин можуть являтися передумовою виникнення надзвичайних ситуацій, оцінювання можливості їх виникнення та наслідків мають містити: окреслення можливості утворення надзвичайних ситуацій та подій; обрахунок уражальних факторів, які формуються ними; окреслення максимальних розмірів зони надзвичайної ситуації та ймовірність утворення вторинних факторів враження; оцінювання наслідків діянь вражальних факторів; узагальнення оцінювань потенційного ризику стосовно їх відповідності принципам прийнятного ризику; визначення особливостей та масштабів аварійно-рятувальних робіт.

Водночас практична робота органів управління та сил цивільного захисту засвідчує, що результативність заходів попередження та мінімізації наслідків надзвичайних ситуацій не завжди адаптована до потреб сьогодення. Наявні упущення в організації реагування на надзвичайні ситуації, ухваленні вчасних та аргументованих рішень, а також у здійсненні аварійнорятувальних та інших невідкладних робіт засвідчують про недостатній ступінь організації управління в надзвичайних ситуаціях. Передумови названих упущень - це, в основному, брак досвіду, а часом i потрібних знань у керівників органів управління.

Варто погодитися з С. Вовченком у тому, що «проблема ліквідації надзвичайних ситуацій (НC) та мінімізації негативних наслідків від них є одним 3 найбільш актуальних і важливих завдань місцевих органів виконавчої влади та органів місцевого самоврядування. Разом 3 тим, практична діяльність органів управління і сил цивільного захисту, ефективність заходів щодо протидії надзвичайним ситуаціям техногенного та природного характеру (управління ризиком) не завжди відповідають вимогам забезпечення необхідного рівня безпеки людини на сучасному етапі розвитку суспільства. Суттєві недоліки в організації оперативного реагування на резонансні НС, прийнятті своєчасних i адекватних оперативній обстановці рішень, а також при проведенні аварійно-рятувальних та інших невідкладних робіт свідчать про недостатній рівень організації управління в НС» [1]. 


\section{Науковий вісник : Державне управління №1 (7) 2021}

Варто зауважити, що до головних напрямків покращення державного управління в галузі захисту мешканців і територій від НС А. Капля зараховує:

«формування нормативно-правової бази 3 техногенної i природної безпеки та гармонізація іï 3 вимогами Європейського Союзу; розширення сфери досліджень і розробок методів, моделей, методик аналізу та оцінки виникнення надзвичайних ситуацій техногенного i природного характеру, прогнозування їх розвитку;

удосконалення системи моніторингу небезпечних техногенних об’єктів і природних процесів у напрямі забезпечення інформаційної бази для оцінки надзвичайних ситуацій;

упровадження нових дієвих форм аналізу, оцінки, експертизи і контролю безпеки небезпечних техногенних об'єктів на всіх етапах життєвого циклу;

формування сучасної інституційної бази регулювання техногенної та природної безпеки;

удосконалення системи освіти та забезпечення підготовки фахівців у галузі управління надзвичайними ситуаціями техногенного і природного характеру» [2].

Водночас, як зазначає $С$. Кобко, «необхідність удосконалення адміністративно-правових заходів запобігання та ліквідації надзвичайних ситуацій визначається наступним:

наявністю значної кількості потенційно небезпечних об'єктів на території;

високим рівнем травматизму та смертності населення, спричинених небезпечними подіями та нещасними випадками; високим рівнем ризиків виникнення надзвичайних ситуацій природного характеру, зумовленого глобальними та регіональними змінами клімату, зростанням сейсмічної активності тощо, а також інтенсифікацією впливу техногенної діяльності людини на навколишнє природне середовище; високим рівнем ризиків виникнення надзвичайних ситуацій, зумовленого критичним ступенем зношеності (60-80\%) 
основних виробничих фондів у галузях промисловості та агропромисловому комплексі;

недостатнім технічним i технологічним рівнем розвитку державної системи спостережень за небезпечними чинниками, що зумовлюють виникнення надзвичайних ситуацій i техногенного, і природного характеру» [3].

Дослідник С. Потеряйко зазначає, що «для удосконалення аналітичного механізму державного управління у надзвичайних ситуаціях пропонується:

проводити спільні міжвідомчі навчання із залученням різнорідних органів управління міністерств, на яких покладено завдання щодо запобігання та ліквідації наслідків надзвичайних ситуацій.

використовувати системи імітаційного моделювання для підготовки органів управління до дій у складних умовах надзвичайних ситуацій під час проведення навчань;

впроваджувати в систему управління силами та засобами цивільного захисту новітніх інформаційних технологій;

розробляти спеціальне математичне програмне забезпечення для вирішення інформаційних та розрахункових задач» [4].

Крім того, серед проблем варто звернути увагу на «недостатній рівень кількісно-якісних показників спеціального математичного та програмного забезпечення вказаних заходів, що не дозволяє значно підвищити оперативність і якість процесу роботи органів управління у надзвичайних ситуаціях. 3 наведеного можна зробити висновки:

рівень автоматизації та ступінь спеціального математичного та програмного забезпечення має значний вплив на роботу органів управління за рахунок автоматизації збору, обробки, збереження інформації, попередньої іiї обробки, моделювання і прогнозування та інше;

сучасний ступінь автоматизації роботи органів управління під час ліквідації наслідків надзвичайних ситуацій дозволяє стверджувати, що не існує єдиної міжвідомчої автоматизованої системи управління силами і засобами, що залучаються до виконання завдань в районі надзвичайної ситуації, а існують 


\section{Науковий вісник : Державне управління №1 (7) 2021}

лише окремі автоматизовані робочі місця, локальні обчислювальні мережі окремих структурних підрозділів (компонентів) сектора безпеки та оборони, а спеціальне математичне i програмне забезпечення дозволяє в автоматизованому режимі вирішити незначну частину інформаційних та розрахункових задач» [4].

Виклад основного матеріалу. На основі аналізу даних нашого дослідження, власного практичного досвіду організації реагування на виникнення НС, ми висуваємо гіпотезу, що критичним протиріччям системи управління попередженням i мінімізацією наслідків виникнення надзвичайних ситуацій $\epsilon$ протиріччя між необхідністю якісного і достатнього рівня матеріально-технічного та фінансового забезпечення сил цивільного захисту та наявним станом його матеріальних резервів, який, згідно законодавчо-нормативного забезпечення повинні створювати всі органи управління, що входять в СДСЦЗ.

Ефективність попередження i мінімізації наслідків при ліквідації НС природного та техногенного характеру головним чином визначається існуванням матеріального ресурсу. Завдяки його достатній кількості можна в мінімальний строк ліквідувати надзвичайні ситуації, знизити обсяги наслідків надзвичайних ситуацій, локалізувати безпосередню загрозу для життя та здоров'я населення та, як результат, вирішити основне завдання врятувати та організувати першочергове життєзабезпечення постраждалих.

В. Свяцький зазначає, що «резерви матеріальних ресурсів для ліквідації НС створюються завчасно, $є$ важливим складеним елементом єдиної державної системи цивільного захисту, призначені для невідкладного залучення необхідних засобів у випадку виникнення НС, спрямовані на порятунок життя i збереження здоров'я людей, зниження розмірів збитку навколишньому природному середовищу і матеріальних втрат, а також на локалізацію зон НС, припинення дії характерних для них небезпечних факторів. Усунення безпосередньої небезпеки для життя і здоров'я людей, інші першочергові заходи, пов'язані iз забезпеченням життєдіяльності населення, - усе це 


\section{Науковий вісник : Державне управління №1 (7) 2021}

здійснюється за рахунок матеріальних цінностей, що входять у резерви» [5]. Автор також зазначає, що «створення i використання резервів матеріальних ресурсів для ліквідації НС повинно визначатися такими принципами:

визначеність иільового призначення - формуються цільові резерви, що враховують потенційні можливості прояву НС відповідно до регіональних, галузевих i виробничих особливостей;

раціональність розміщчення - забезпечення максимального рівня матеріальних резервів; дислокація їх у місцях, виходячи 3 оцінки імовірності ризику виникнення в них надзвичайних ситуацій;

економічність - величина витрат, які виділяються на створення, зберігання, використання i заповнення резервів матеріальних ресурсів для ліквідації НС, повинна визначатися у відповідності із імовірною НС, прогнозованим збитком, програмою і послідовністю проведення невідкладних робіт, специфікою регіону або об'єкта;

керованість - відповідність системи керування усіма структурами різного рівня під час створення і використання матеріальних ресурсів;

мобільність - підтримка високого рівня підготовленості резервів до оперативного переміщення в зони НС, а також здійснення приймання, переробки і підготовки матеріальних ресурсів резервів до використання при ліквідації НС;

достатність - величина резервів, їхня структура, асортименти, якісні показники i характеристики повинні забезпечувати проведення невідкладних робіт 3 ліквідації надзвичайних ситуацій відповідно до специфіки регіону або об’єкта, виду НС» [5].

У законодавстві зазначається, що «дуже важливою складовою системи реагування на НС є їі матеріально-технічне та фінансове забезпечення, яке здійснюється шляхом завчасного утворення державою запасів зазначених ресурсів та їх залучення у встановленому порядку під час виникнення НС з особливо тяжкими наслідками, 3 метою їх ліквідації. Зокрема, 3 метою 


\section{Науковий вісник : Державне управління №1 (7) 2021}

задоволення потреб сил ЦЗ в аварійно-рятувальній та спеціальній техніці, озброєнні, пальному, продовольстві, речовому, технічному, медичному майні та інших матеріальних засобах здійснюється комплекс заходів по їх придбанню та накопиченню, який включає: замовлення, постачання, отримання і створення запасів матеріальних засобів, їх зберігання, поповнення, відправку і підвезення споживачам, а також маневр запасами i резервами. Зазначені ресурси є складовою державного резерву, структура та порядок управління яким визначаються Кабінетом Міністрів України» [6].

В Україні матеріальні ресурси, які застосовуються для запобігання ліквідації НС техногенного і природного характеру та їх наслідків, повинні формуватися:

Кабінетом Міністрів України - державний резерв (стратегічний резерв) для здійснення першочергової діяльності 3 ліквідації наслідків НС та надання невідкладної допомоги потерпілим мешканцям;

ДСНС - оперативний резерв для реагування на надзвичайні події та надання термінової невідкладної допомоги постраждалому населенню;

міністерствами та відомствами (відповідно до характеру діяльності) - відомчий резерв для запобігання НС та усунення їхніх наслідків;

обласними, міськими, районними державними адміністраціями та виконкомами рад міст обласного значення - регіональний та місцевий резерви для здійснення заходів, скерованих на запобігання, усунення НС техногенного i природного характеру та їх наслідків, і надання невідкладної допомоги потерпілим мешканцям;

суб'єктами господарської діяльності, у власності (управлінні) чи в користуванні котрих наявний об'єкт (об'єкти) підвищеної небезпеки, - об'єктовий запас для запобігання, ліквідації НС техногенного i природного характеру та їх наслідків, проведення термінових відновлювальних робіт.

На думку О. Тарасюка, «в Україні, як і в інших країнах резерви є власністю держави і повністю нею контролюються. 


\section{Науковий вісник : Державне управління №1 (7) 2021}

Перевага такого принципу полягає в можливості оперативно реагувати на ситуацію й уникати втручання в діяльність приватних компаній. Головним недоліком $є$ великі бюджетні витрати на створення i підтримку резервів, необхідність утримання апарату спеціального відомства» [7].

Однак на основі власних спостережень практики реагування на надзвичайну ситуацію, що пов'язана із розповсюдженням корона вірусу Covid-19, аналізу результатів включеного спостереження за функціонуванням територіальної підсистеми ЄДСЦЗ, що проведене Є. Литвиновським [8], можна засвідчити, що матеріальні резерви не були накопичені, у даному випадку. Наприклад, медичні лабораторії не можливо було розгорнути, служба медичного захисту існувала лише в розпорядчих документах, які не оновлювались з 2017 року.

На основі аналізу результатів дослідження О. Тарасюка можна стверджувати, що це не нова проблема. Низький рівень резервування існує 32012 року. Автор у своєму дослідженні зазначає «на сьогоднішній день (2012 - ремарка В. Маслей) існують інші проблеми державного матеріального резервування, серед яких:

фактичні запаси матеріальних цінностей не відповідають затвердженим рівням;

відсутня методика визначення номенклатури матеріальних цінностей, що закладаються на зберігання до державного резерву;

потужності підприємств, що входять до системи державного матеріального резерву, застарілі і не відповідають вимогам сучасності» [7].

Отже, можна констатувати, що протягом останніх сьоми років існує критичне протиріччя між необхідністю наявного достатнього матеріально-технічного забезпечення системи управління попередженням та мінімізацією наслідків надзвичайних ситуацій та наявним станом його матеріального резерву. Це негативно вплинуло на реагування на $\mathrm{HC}$, що пов'язана з розповсюдженням корона вірусу. Наслідки такого 


\section{Науковий вісник : Державне управління №1 (7) 2021}

стану ще буде потрібно оцінити в подальших наукових дослідженнях.

Для подолання зазначеного протиріччя негайними кроками щодо його подолання ми визначаємо кроки щодо поліпшення системи державного матеріального резервування, а саме:

дослідження зарубіжної практики державного резервування, щоб визначити найоптимальніші зразки державного резервування для України, 3 наступним впровадженням потрібних реформ;

удосконалення системної нормативно-правової бази; напрацювання методів визначення номенклатури матеріальних надбань з приведенням розрахунків норм їх нагромадження; реконструкція підприємств, які належать до системи держрезерву.

Методика розрахунку матеріальних резервів як інструмент механізму державного управління силами цивільного захисту запропонована В. Єлісєєвим, А. Пруським, В. Тищенком [10]. Однак іiі застосування потребує проведення емпіричних досліджень з метою доведення іï̈ валідності.

Для розв'язання зазначеного протиріччя важливим $\epsilon$ створення системи логістики матеріальних резервів системи управління попередженням та мінімізацією наслідків виникнення надзвичайних ситуацій. Керування потоками матеріальних резервів як будь-яким іншим об'єктом, передбачає дві складові: ухвалення рішень та їх виконання. Для того, щоб ухвалювати обгрунтовані рішення 3 управління матеріальними потоками, потрібні відповідні знання, що відносяться до логістичних систем. Таким чином, дефініцію логістики в системі управління матеріальними потоками можна визначити так: міждисциплінарний науково-практичний напрям 3 оптимізації діяльності органів і сил СДСЦЗ та покращення організації 3 створення, накопичення, збереження та використання матеріальних резервів, що передбачає аналіз, розрахунок та прогнозування ймовірних потоків із врахування результатів моделювання негативних факторів різних техногенних, природних та соціальних надзвичайних ситуацій, ефективне 


\section{Науковий вісник : Державне управління №1 (7) 2021}

управління

зустрічними

матеріальними

потоками

переміщенням сил і засобів, накопичення та зберігання майна, інформаційних потоків, які їх супроводжують, зважаючи на наявні ліміти часу та ресурсів.

Висновки та напрями подальшого дослідження. Аналіз зазначених вище досліджень 3 питань розв'язання проблем системи управління функціонуванням СДСЦЗ свідчить, що в основі ї такі протиріччя: збільшення кількості та ускладненні суті завдань, які виникають в керівника робіт 3 ліквідації наслідків НС та його недостатньою професійною компетентністю; необхідність функціонування системи автоматизації управління та моделювання виникненням надзвичайних ситуацій та його наявним станом; наявністю значної кількості потенційно небезпечних об'єктів на території України та рівнем зношеності їх основних фондів.

Однак, критичним протиріччям функціонування системи попередження та мінімізації наслідків надзвичайних ситуацій як складової системи управління ЄДСЦЗ визначено протиріччя між необхідністю наявного достатнього рівня сучасного матеріального забезпечення сил реагування та наявним рівнем матеріального резерву.

Враховуючи поточні та перспективні завдання України, практику управління ризиками варто переглянути значення державних матеріальних резервів у системі забезпечення функціонування системи управління попередженням та мінімізацією наслідків виникнення надзвичайних ситуацій.

Негайними кроками щодо його подолання є: дослідження зарубіжної практики державного резервування, щоб визначити найоптимальніші зразки державного резервування для України, 3 наступним впровадженням потрібних реформ; удосконалення системної нормативно-правової бази; напрацювання методів визначення номенклатури матеріальних надбань 3 приведенням розрахунків норм їх нагромадження; реконструкція підприємств, які належать до системи держрезерву. 


\section{Науковий вісник : Державне управління №1 (7) 2021}

Крім того, важливим $є$ створення системи логістики матеріальних резервів системи управління попередженням та мінімізацією наслідків виникнення надзвичайних ситуацій.

Напрямами подальшого дослідження $є$ розробка пропозицій щодо створення єдиного протоколу державного резервування 3 метою подолання критичного протиріччя функціонування системи управління попередженням та мінімізацією наслідків виникнення надзвичайних ситуацій.

\section{Список використаних джерел}

1. Вовченко С. Основні напрямки удосконалення функціонування органів управління щодо попередження та ліквідації надзвичайних ситуацій на регіональному рівні. Актуальні проблеми державного управління. 2012. Вип. 4. С. $56-61$.

2. Капля А. М., Чубань В. С., Снісар О. Г. Удосконалення державного управління систем запобігання і реагування на надзвичайні ситуації в Україні з використанням досвіду зарубіжних країн: проблеми та перспективи. Пожежна безпека: теорія $і$ практика; Академія пожежної безпеки ім. Героїв Чорнобиля. 2013. № 14. С. 39 - 46.

3. Кобко Є. В. Шляхи удосконалення адміністративно-правових заходів запобігання та ліквідації надзвичайних ситуацій техногенного характеру. Науковий вісник Львівського державного університету внутрішніх справ. серія юридична. 2017. Вип. 1. С. $202-211$.

4. Свяцький В. В. Скрипник О. В. Резерви матеріальних ресурсів в системі безпеки життєдіяльності. Kluczowe aspekty naukowej działalności 2016 : materiały XII Międzynarodowejnaukowipraktycznejkonferencji (7 - 15 stycznia 2016 roku). Przemyśl, RzeczpospolitaPolska. Przemyśl: Sp. z o.o. Nauka i studia, 2016. Vol. 8. Matematyka. Fizyka. Budownictwo i architektura. Rolnictwo. Technicznenauki. S. $67-69$.

5. Потеряйко С. П., Барило О. Г. Напрями удосконалення інформаційно-аналітичного механізму державного управління у надзвичайних ситуаціях. Науковий збірник Інституту державного управління у сфері иивільного захисту. 2017. № 5. С. 62 - 74.

6. Про державний матеріальний резерв : Закон України. Відомості Верховної Ради України, 1997, № 13, ст. 112.

7. Тарасюк О. Б. Кас'янова О. О. Сутність державного матеріального резервування. Актуальні проблеми економіки. 2012. № 6. С. 91 - 95. 
8. Литвиновський Є. Ю. Деякі результати спостереження за організацією функціонування територіальної підсистеми єдиної державної системи цивільного захисту. Науковий вісник : державне управління. №4(6). 2020. С. 160-185. URL : https://doi.org/10.32689/2618-0065-2020-4(6)-160-185 (дата звернення 30.12.2020)

9. Пруський А. В., Тищенко В. О., Власенко С. О. Методика розрахунку матеріальних резервів як інструмент механізму державного управління силами цивільного захисту. Науковий вісник : Державне управління №4(6). С. 122-142. URL : https://doi.org/10.32689/26180065-2020-4(6)-122-142 (дата звернення 30.12.2020).

\section{References}

1. Vovchenko, S. (2012) Osnovni napriamky udoskonalennia funktsionuvannia orhaniv upravlinnia shchodo poperedzhennia ta likvidatsii nadzvychainykh sytuatsii na rehionalnomu rivni [The main directions of improving the functioning of government agencies for the prevention and elimination of emergencies at the regional level]. Aktualni problemy derzhavnoho upravlinnia -Actual problems of public administration, 4, 56 - 61 [in Ukrainian].

2. Kaplia, A. M., Chuban, V. S. \& Snisar, O. H. (2013) Udoskonalennia derzhavnoho upravlinnia system zapobihannia i reahuvannia na nadzvychaini sytuatsii v Ukraini z vykorystanniam dosvidu zarubizhnykh krain: problemy ta perspektyvy [Improving public administration of emergency prevention and response systems in Ukraine using the experience of foreign countries: problems and prospects]. Pozhezhna bezpeka: teoriia i praktyka - Fire safety: theory and practice, 14, 39 - 46 [in Ukrainian].

3. Kobko, Ye. V. (2017) Shliakhy udoskonalennia administratyvnopravovykh zakhodiv zapobihannia ta likvidatsii nadzvychainykh sytuatsii tekhnohennoho kharakteru [Ways to improve administrative and legal measures to prevent and eliminate emergencies of man-made nature]. Naukovyi visnyk Lvivskoho derzhavnoho universytetu vnutrishnikh sprav. seriia yurydychna - Scientific Bulletin of Lviv State University of Internal Affairs. legal series, 1, 202-211 [in Ukrainian].

4. Sviatskyi, V. V. \& Skrypnyk, O. V. (2016) Rezervy materialnykh resursiv $\mathrm{V}$ systemi bezpeky zhyttiediialnosti [Reserves of material resources in the system of life safety] Kluczoweaspektynaukowejdziałalności. Materiały XII Międzynarodowejnaukowi-praktycznejkonferencji - Materials of the XII International Scientific-Practical Conference. Przemyśl: Sp. z o.o. Nauka i studia (Vol. 8) (pp. 67 - 69) [in Ukrainian]. 
5. Poteriaiko, S. P. \& Barylo, O. Hr. (2017) Napriamy udoskonalennia informatsiino-analitychnoho mekhanizmu derzhavnoho upravlinnia $u$ nadzvychainykh sytuatsiiakh [Directions for improving the information and analytical mechanism of public administration in emergencies]. Naukovyi zbirnyk Instytutu derzhavnoho upravlinnia u sferi tsyvilnoho zakhystu - Scientific collection of the Institute of Public Administration in the field of civil protection, 5, 62 - 74 [in Ukrainian].

6. Zakon Ukrainy Pro derzhavnyi materialnyi rezerv: pryiniatyi 24 sich. 1997 roku № 51/97-VR [Law of Ukraine On State Material Reserve from January 24 1997, № 51/97-VR]. (1997). Vidomosti Verkhovnoi Rady Ukrainy - Information of the Verkhovna Rada of Ukraine, 13, st. 112 [in Ukrainian].

7. Tarasiuk, O. B. \& Kasianova, O. O. (2012) Sutnist derzhavnoho materialnoho rezervuvannia [The essence of the state material reserve]. Aktualni problemy ekonomiky - Actual problems of economics, 6, 91-95 [in Ukrainian].

8. Lytvynovskyi Ye. Yu. Deiaki rezultaty sposterezhennia za orhanizatsiieiu funktsionuvannia terytorialnoi pidsystemy yedynoi derzhavnoi systemy tsyvilnoho zakhystu. [Some results of observation of the organization of functioning of the territorial subsystem of the unified state system of civil defense]. Naukovyi visnyk : derzhavne upravlinnia. №4(6). 2020. S. 160185.. №4 (6). 2020. S. 160-185. URL: https://doi.org/10.32689/26180065-2020-4(6)-160-185 (accessed 30.12.2020) [in Ukrainian].

9. Prusky A. V., Tishchenko V. O., Vlasenko E. A. (2020) Metodyka rozrakhunku materialnykh rezerviv yak instrument mekhanizmu derzhavnoho upravlinnia sylamy tsyvilnoho zakhystu. [Methodology of calculation of material reserves as a tool of the mechanism of state management of civil defense forces]. Scientific Bulletin: Public Administration №4 (6). Pp. $122 \quad-\quad$ 142. URL: https://doi.org/10.32689/2618-0065-2020-4(6)-122-142 (accessed 30.12.2020) [in Ukrainian]. 
Науковий вісник : Державне управління №1 (7) 2021

\title{
DETERMINATION OF A CRITICAL CONTRADICTION IN THE FUNCTIONING OF THE PREVENTION MANAGEMENT SYSTEM AND MINIMIZATION OF THE CONSEQUENCES OF EMERGENCIES
}

\begin{abstract}
Maslei Viktor
Abstract. The most pressing problem in today's conditions, which is fraught with a significant number of emergencies with a significant amount of their consequences, is to increase the safety of the population during emergencies. Thanks to the work of executive authorities, local governments, the State Emergency Service of Ukraine, scientific institutions, a number of laws and regulations have been developed and adopted to establish management of emergency prevention and response, and significant experience has been gained in implementing measures to prevent accidents and catastrophes. and natural disasters, as well as the elimination of their consequences. The article, based on the analysis of previous studies, outlines the shortcomings of response measures and minimization of the consequences of emergencies, consisting in the presence of omissions in the management system to respond to them, in making unpopular and unsubstantiated decisions in emergency rescue and other urgent works, insufficient the level of quantitative and qualitative indicators of special mathematical and software for modeling these measures. The main prerequisites for these omissions are the lack of experience and knowledge required by the heads of government. The critical contradiction in the functioning of the emergency prevention and minimization management system is the contradiction between the need for a sufficient level of logistical and financial support of the emergency prevention and minimization management system and the low level of available material reserve to be created by management bodies of the unified state system of civil protection at all levels. The article analyzes the regulatory and legal support for the creation of material reserves in order to determine the degree of responsibility of authorities at different levels for their creation. Proposals were made to overcome this critical contradiction, namely to determine the most optimal state reserve protocol for Ukraine, followed by the implementation of the necessary reforms; improvement of the system regulatory framework; development of methods for determining the nomenclature of material possessions with the calculation of the norms of their accumulation; reconstruction of enterprises belonging to the state reserve system. Also the main thing is the creation of a logistics system with a material reserve, the author's definition of this definition is given. Conclusions are made and it is determined that the directions of further research are the development of proposals for the creation of a single protocol of the state reserve in order to overcome the critical contradiction of the functioning of the management system for prevention and minimization of the consequences of emergencies.
\end{abstract}

Key words: emergency situation, State Service of Ukraine for Emergencies, material reserve, state material reserve, management system, logistical support, prevention and minimization of consequences of emergencies. 